\title{
Crowdfunding Platform as Waqf Land Financing Model: A Case of Muhammadiyah Waqf Institution
}

\author{
Fahmi Medias $^{1}$, Zulfikar Bagus Pambuko ${ }^{2}$, Emilya Ully Artha $^{3}$ \\ \{zulfikar.bp@unimma.ac.id $\left.{ }^{2}\right\}$ \\ Universitas Muhammadiyah Magelang, Magelang, Indonesia ${ }^{1,2,3}$
}

\begin{abstract}
This Muhammadiyah institutions in Indonesia face various difficulties in developing their waqf land. For instance, the financial sources are often inadequate, limiting development. The purpose of this paper is to propose an alternative financing model in the form of a waqf crowdfunding platform for Muhammadiyah institutions in dealing with financial problems. This research offers a crowdfunding platform model to be used by Muhammadiyah waqf institutions, especially in Central Java, in financingrelated projects. In general, the study analyses the inefficiency of Muhammadiyah waqf management in Central Java due to the problem of financing waqf projects. A waqf crowdfunding platform model has been developed as a source of funds for Muhammadiyah waqf institutions. It is expected to be a solution for the empowerment of Muhammadiyah non-productive waqf land. The institutions may have to find alternative solutions for the development of waqf for the people. The findings of this study provide material information and input for Muhammadiyah Waqf Institutions through crowdfunding platforms. Through this model, Muhammadiyah waqf might become more useful in solving economic and social problems for the Ummah, especially in Central Java.
\end{abstract}

Keywords: Muhammadiyah; Waqf; JariyahMu; Fundraising

\section{Introduction}

Through Law No. 41 of 2004 on waqf, Indonesia has legitimized the management of waqf institutions to the government as well as to all elements of society [1]. This includes the Muhammadiyah Persyarikatan appointed as nazhir through a Decree of the Minister of Home Affairs in 1972 [2]. From the portal http://sikafmujateng.org/, Majelis Wakaf dan Kehartabendaan Central Java has managed waqf totaling to 2,834 lands in an area of $206.34 \mathrm{Ha}$. Nevertheless, the majority of Muhammadiyah waqf land in Central Java serves as mosques, prayer rooms, or educational institutions (Table 1) [3].

Table 1. Muhammadiyah waqf land categories

\begin{tabular}{lll}
\hline No & Types of waqf & Percentage \\
\hline 1 & Mosques & $20.72 \%$ \\
2 & Clinics and hospitals & $3.6 \%$ \\
3 & Schools & $49.55 \%$ \\
4 & Orphanages & $26.13 \%$ \\
& Total & $100 \%$ \\
\hline
\end{tabular}

Sources: Majelis Wakaf dan Kehartabendaan reports 
According to Table 1,70.27\% of Muhammadiyah's waqf land is used as religious and educational facilities. This portion has not contributed to the development of the economic sector. The primary goal of waqf is to cater for the welfare of the Ummah [4]. Unfortunately, there is a lack of financial resources, leading to a gap in developing assets and classical management patterns in managing waqf land [5].

Therefore, the development of Muhammadiyah waqf land requires other innovative financial resource systems [6]. The financial resource challenges faced by Muhammadiyah's waqf institution form the basis of this research. The study proposes a new and sustainable model for development through the crowdfunding waqf model (CWM). Moreover, the CWM is expected to be the most appropriate and adequate funding system in overcoming financial problems faced by Muhammadiyah waqf institutions [7]. It utilizes internet-based innovation for the development of waqf projects which have proven successful in several countries, such as the United Kingdom, Canada, France, and Brazil [8]. The potential of the funding system through this model is excellent in case it is applied to Muhammadiyah waqf institutions. The funds raised from crowd investors help in developing the Muhammadiyah waqf project based on donations instead of cash.

The purpose of this study aims to propose a funding system that overcomes the problem of financing waqf land faced by Muhammadiyah waqf institutions. It recommends the development of policies to enhance the role of CWM in the management of waqf land.

\section{Literature Review}

Research on waqf has been carried out to analyze its management in Muslim countries. This research begins with a previous study of the vital role of waqf in the welfare of the Ummah. Non-profit sectors, such as waqf, have a significant role in world social justice, which connects the enriched parties with the ones in need of it [9]. The concept offered is different and offers Sukuk al-intifa' $a$ as an alternative model of critical financial instruments. It has the potential to support productive waqf management, making it a significant source of funds in developing the country's economy [10].

Previous works focused a lot on the normative aspects related to the role of cash waqf in poverty alleviation in Indonesia, the contribution of the Waqf Bank to the social welfare of the community, and the management of waqf through a community approach [11]-[13].

However, studies of waqf tend to focus solely on social frameworks. For instance, previous studies have not discussed and tried to formulate Indonesia's economic problems into alternative sustainable systems or models such as crowdfunding.

The crowdfunding platform refers to the efforts of a group of individuals to raise finances through the internet to support projects offered by Nazhirs waqf [14]. The most appropriate category to be applied to the waqf crowdfunding platform is the donation model, following McGrail's explanation that the crowdfunding platform donation model is usually referred to as non-profit agencies, including waqf institutions [15].

Not-for-profit crowdfunding contains projects that do not aim to generate profits [16]. However, donation-based crowdfunding applied to non-profit institutions provides a return in the form of social gains [17]. Crowdfunding in the field of waqf might be funded by waqf from the community, which in general is an essential source of funding amid the problem of the development of waqf land. 
From previous studies, the crowdfunding model in the development of Muhammadiyah waqf land has not been discussed sufficiently. This model is expected to make waqf more productive for community development.

\section{Proposed Model}

The crowdfunding model proposed involves three parties, the Muhammadiyah waqf institution, administrators, and crowd funders (investors). The Crowd funders consists of donors who provide and donate funds for the Muhammadiyah waqf project. A lot of waqf crowdfunding project initiators are not interested in managing the related processes, and therefore they need the help of intermediaries. The administrator acts as a facilitator between the project initiator and the donor. Additionally, the administrator is an intermediary between the waqf project donors and the manager, in this case, the Muhammadiyah waqf institution.

This model shows an alternative approach for Muhammadiyah institutions in developing consumptive waqf land to be productive. In Central Java, donation-based crowdfunding is a model to be applied to the proposed CWM (Figure 1).

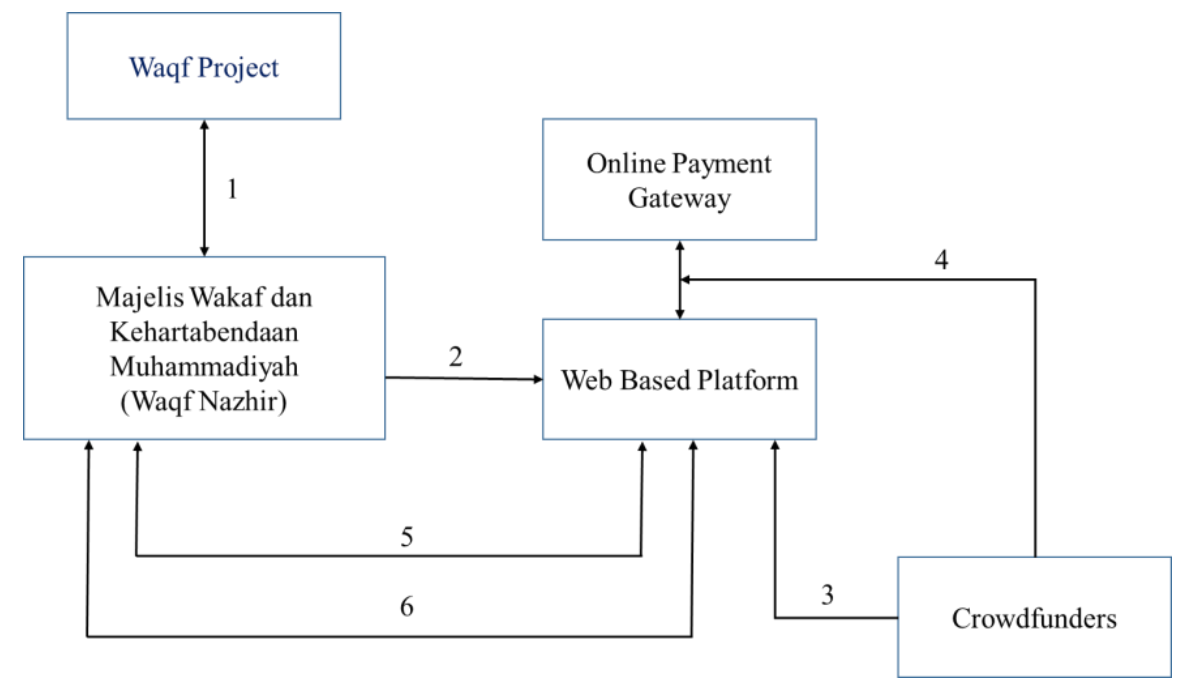

Fig. 1. Alternative waqf crowdfunding models

The following is an explanation regarding the flow of the CWM process for Muhammadiyah waqf institutions:

a. Muhammadiyah waqf institution in Central Java plans to develop waqf land through several projects such as hotels, buildings, shopping centre, and hospitals. It then identified the waqf land and its potential and conducted a promotion to obtain funds from donors;

b. The institutions submit proposals to administrators through the platform by determining the funding period;

c. Donors choose the projects to fund through project-tracking on the platform;

d. Donors send funds through online payment of financial bodies collaborated with Muhammadiyah Central Java waqf institutions; 
e. In case the funding target is met, the platform updates the status of the project and donations to be distributed to the Muhammadiyah endowments;

f. Administrators through the platform distribute donations to Nazim waqf Muhammadiyah;

g. Nazir waqf manages donations and updates the progress of the project into the system to ensure transparency of management; and

h. Administrators submit reports on the management of endowment donations to donors through the platform.

From the waqf crowdfunding model (Figure 2), namely JariyahMu, Muhammadiyah waqf institutions and crowdfunding platforms might be mutually beneficial. With the donations from crowd funders, the financing problem, the main inhibiting factor in the empowerment of waqf land, is overcome easily [18]. Therefore, a crowdfunding platform has a positive impact on Muhammadiyah waqf institutions, the community, and the Indonesian economic sector.

The crowdfunding model is useful for Muhammadiyah waqf institutions to achieve the main objectives of waqf and for the initiated projects to be successful. A lot of donors might be interested in funding projects socialized through the platform [19]. In consequence, Muhammadiyah waqf institutions in Central Java might meet their consumptive waqf financing without having to rely on cash waqf.

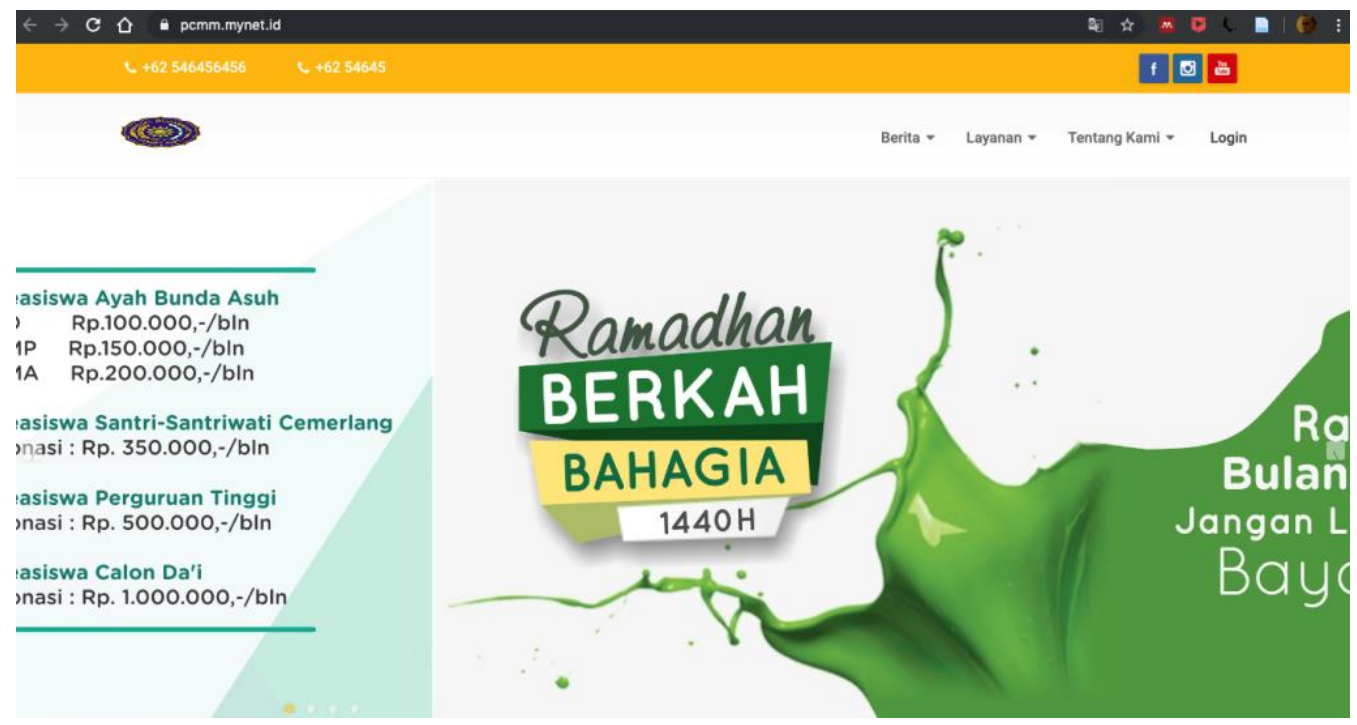

Fig. 2. WakafMu crowdfunding platform

This model is also expected to bring broader benefits to the community economy. This is because it places more emphasis on land empowerment that stimulates the development of the economy of the region. Besides, these projects might bring jobs to the community and help in poverty alleviation. Crowdfunding, in the end, is a system of income allocation and distribution of wealth as regulated in religion. 


\section{Future Research Direction}

Future studies need to examine the relationship between platforms and donors on operational performance. The dimensions of this study are derived from the literature on accepting donors using platforms through survey methods with the Technology Acceptance Model analysis technique. The goal is to determine the shortcomings and conveniences received by donors while using it.

\section{Conclusion}

This research shows that the majority of Muhammadiyah waqf land is managed consumptively. The institutions in Central Java face financing problems in managing land entrusted to them by waqf. The lack of funds is considered as a significant factor that significantly influences the success of Muhammadiyah waqf management. This study proposes a crowdfunding model as a solution to overcome the financing constraints. This might help of waqf increase the role of waqf and its contribution to the socio-economic welfare of the community.

\section{Acknowledgement}

The authors would like to thank the Ministry of Research, Technology and Higher Education of the Republic of Indonesia for its research grant that enabled us to conduct this research.

\section{References}

[1] A. Rosadi, D. Effendi, and B. Busro, "The Development of Waqf Management Throught Waqf Act in Indonesia (Note on Republic of Indonesia Act Number 41 of 2004 regarding Waqf)," Madania: Jurnal Kajian Keislaman, vol. 22, no. 1, p. 1, 2018.

[2] C. Solihah, D. Mulyadi, and H. Nur, "Muhammadiyah Nazhir Organization Analysis of Waqf Management and Development in Cianjur," Jurnal Dinamika Hukum, vol. 17, no. 2, p. 125, 2017.

[3] F. Medias and E. K. Pratiwi, "The Evaluation of Muhammadiyah Waqf Asset Utilisation in Magelang,” IQTISHADIA, vol. 12, no. 1, pp. 101-118, 2019.

[4] H. A. Mutalib and S. Maamor, "Utilization of Waqf Property: Analyzing an Institutional Mutawalli Challenges in Management Practices," International Journal of Economics and Financial Issues International Journal of Economics and Financial IssuesInternational Soft Science Conference, vol. 6, no. S7, pp. 36-41, 2016.

[5] N. M. Ali;, R. Ahmad, and N. S. A. Mahdzan, "The need of an effective business model for waqf land development in Malaysia," in 20th International Research Conferences on Business, Economics and Social Sciences, 2015, no. I, pp. 1-12.

[6] M. A. Bin Mohd Thas Thaker and A. Allah Pitchay, "Developing waqf land through crowdfundingwaqf model (CWM): the case of Malaysia," Journal of Islamic Accounting and Business Research, vol. 9, no. 3, pp. 448-456, 2017. 
[7] C. Martínez-Climent, R. Costa-Climent, and P. Oghazi, "Sustainable Financing through Crowdfunding," Sustainability, vol. 11, no. 3, p. 934, 2019.

[8] The World Bank, "Crowdfunding's Potential for the Developing World," in Finance and Private Sector Development Department, 2013, pp. 1-102.

[9] M. Kahf, "The Role of Waqf In Improving The Ummah Welfare," The International Seminar on "Waqf as a Private Legal Body," pp. 1-26, 2003.

[10] M. Kholid, R. Sukmana, and K. Hassan, "Waqf through Sukuk Al-Intifa'a: A Proposed Generic Model," Awqaf Journal, vol. 17, no. 1, pp. 1-16, 2008.

[11] D. Masyita, M. Tasrif, and A. S. Telaga, "A dynamic model for cash waqf management as one of the alternative instruments for the poverty alleviation in Indonesia," in The 23rd International Conference of The System Dynamics Society Massachussets Institute of Technology (MIT), 2005, pp. 1-29.

[12] G. Baharuddin and B. Taufiq, "The Emergence of Waqf Bank: A Social welfare Alternative in Indonesia," in Advanced Course on Social and Ecological Market Economy, 2015, no. March, pp. 31-39.

[13] F. A. Al Hasan, "Waqf management in Indonesia through asset based community development (ABCD) approach,” International Journal of Social Science and Economic, vol. 2, no. 08, pp. 4070 4087, 2017.

[14] A. A. Pitchay, M. A. Mohd Thas Thaker, A. A. Mydin, Z. Azhar, and A. R. Abdul Latiff, "Cooperative-waqf model: a proposal to develop idle waqf lands in Malaysia," ISRA International Journal of Islamic Finance, vol. 10, no. 2, pp. 225-236, 2018.

[15] D. McGrail, Crowdfunding a Chapter 11 Plan. 2013.

[16] J. Hemer, “A snapshot on crowdfunding (No. R2/2011)," 2011.

[17] S. Arefeen, N. Hoque, A. Mamun, M. Masrurul Mowla, and M. Hasmat Ali, "Use of Crowdfunding for Developing Social Enterprises: An Islamic Approach," International Journal of Business and Management, vol. 13, no. 6, p. 156, 2018.

[18] N. Noordin, N. L. M. Noor, and Z. Samicho, "Strategic Approach to Halal Certification System: An Ecosystem Perspective," Procedia - Social and Behavioral Sciences, vol. 121, no. 1, pp. 79-95, 2014.

[19] European Commission, "Support for continued data collection and analysis concerning mobility patterns and career paths of researchers," Brussle, 2013.

[20] T. A. Judge, R. F. Piccolo, N. P. Podsakoff, J. C. Shaw, and B. L. Rich, "The relationship between pay and job satisfaction: A meta-analysis of the literature," Journal of Vocational Behavior, vol. 77, no. 2, pp. 157-167, 2010.

[21] A. Chamberlain, "Is Salary Transparency More Than a Trend?," Mill Valley, 2015. 